\title{
Knowledge and attitude toward hemoglobinopathies premarital screening program among unmarried population in western Saudi Arabia
}

Safia M. Binshihon, Medical Student, Manal O. Alsulami, Medical Student, Wed M. Alogaibi, Medical Student, Asmaa H. Mohammedsaleh, Medical Student, Hayfa N. Mandourah, Medical Student, Bushra S. Albaity, Medical Student, Mohamad H. Qari, FRCPA, MBBS.

\begin{abstract}

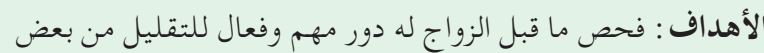

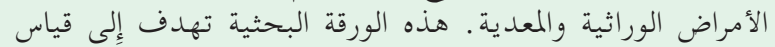

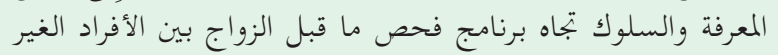

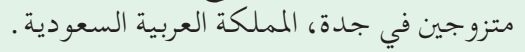
الطريقة: في دراسة مستعرضة أجريت على 1039 ذكر ووانثى ميتى

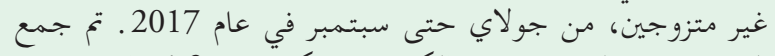

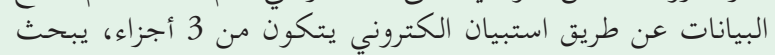

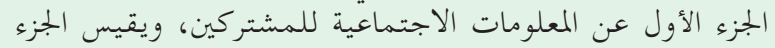

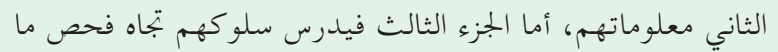
قبل الزواج

النتائج : أشارت النتائج أن نصف المشتركين لديهمم معلومات ضعيفة

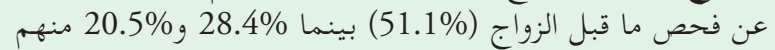

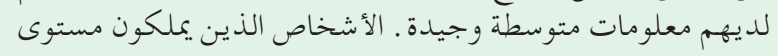

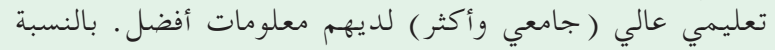

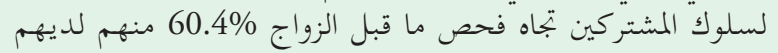

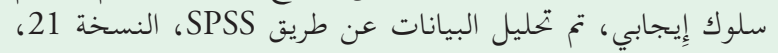

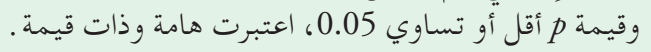

الخاتمة: تشير الدراسة أن أغلب المشتركين لديهم نقص في المعلو مات

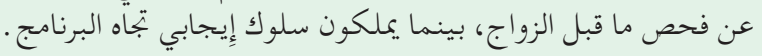

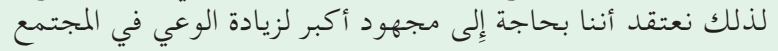

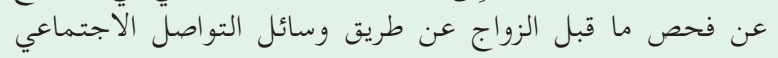

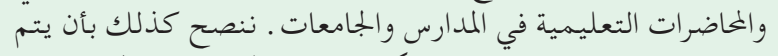

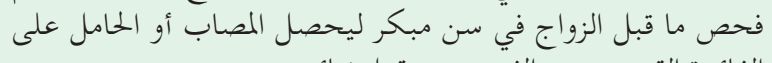

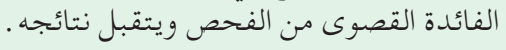

Objectives: To assess the knowledge and attitude toward hemoglobinopathies premarital screening (PMS) program among unmarried population in Jeddah, Kingdom of Saudi Arabia.
Methods: A cross-sectional study was conducted among 1039 unmarried males and females from the general population who fulfilled the eligibility criteria. Data was collected from July-December 2017, using an electronic questionnaire to assess the socio-demographic data, knowledge and attitudes of the participants regarding PMS.

Results: Approximately half of the participants had poor knowledge scores $(51.1 \%)$, while $28.4 \%$ of them had fair and $20.5 \%$ had good scores. Individuals with an educational level of "university degree and above" had significantly higher knowledge than those with lower educational levels. Furthermore, $60.4 \%$ of the participants had a positive attitude toward PMS. The data was analyzed using the Statistical Package for the Social Sciences (SPSS) Version 21 (IBM Corp., Armonk, NY, USA); and a Chi-squared test was used for comparisons between proportions and a $p$-value $\leq 0.05$ was considered significant.

Conclusion: Participants showed a lack of knowledge regarding PMS but they had a positive attitude towards the program. More efforts are required to raise awareness in the public regarding PMS, via social media and educational lectures in schools and universities. Additionally, early genetic screening may help improve test acceptance and higher impact.

Saudi Med J 2018; Vol. 39 (12): 1226-1231

doi: $10.15537 /$ smj.2018.12.23136

From the Department of Hematology, King Abdulaziz University, Jeddah, Kingdom of Saudi Arabia.

Received 8th July 2018. Accepted 6th November 2018.

Address correspondence and reprint request to: Dr. Safia M. Binshihon, Department of Hematology, King Abdulaziz University, Jeddah, Kingdom of Saudi Arabia.E-mail: soofe411@gmail.com

ORCID ID: orcid.org/0000-0002-2684-6261 
T he premarital screening program is a comprehensive program that aims to limit the spread of genetic hemoglobinopathies such as sickle cell anemia (SCA) and thalassemia, in addition to infectious diseases such as hepatitis B and C, and human immunodeficiency virus/acquired immune deficiency syndrome (HIV/ AIDS). ${ }^{1}$ Currently, hemoglobinopathies are the most common inherited disorders worldwide. According to the World Health Organization (WHO), approximately 240 million people are heterozygous for inherited hemoglobinopathies, including thalassemia and SCA. ${ }^{2-5}$

In the Kingdom of Saudi Arabia (KSA), thalassemia major and SCA are the most common genetic disorders. According to the General Statistics Organization, KSA, the prevalence carriers of these disease traits was $1-5 \%$ for beta-thalassemia ${ }^{6}$ and $17 \%$ for SCA traits. ${ }^{7}$ This high incidence could be attributed to traditional marriage and cultural practices that encourage consanguineous and other forms of endogamy marriages. ${ }^{8}$ Therefore, as a preventive measure, a mandatory PMS program was introduced for all Saudis in KSA, in February 2004, based on the Royal decree of 2002. However, prospective couples are not obliged to commit to the laboratory results. ${ }^{9}$ Consequently, PMS has had a highly positive impact on reducing the burden and cost of treatment of hemoglobinopathies, especially that the estimated annual cost of treatment is approximately 100,000 Saudi Riyals (SR) for each individual with thalassemia or SCA, and 120,000 SR for hepatitis B or AIDS. ${ }^{10}$ A previous study conducted on the general population in Riyadh, KSA, found that the majority of the participants had a fair level of knowledge regarding the nature of PMS tests. ${ }^{11}$ Approximately 60\% of all participants preferred to prevent a marriage that is at-risk. ${ }^{11}$ In contrast, another study conducted in Jeddah, KSA, among outpatient clinics in 2012 suggested that the participants' knowledge about the program was low. However, 96\% of all participants believed that the PMS program is an important preventive measure. ${ }^{12}$ In $2005-2006,{ }^{8}$ a study showed that $90 \%$ of the couples choose to marry regardless of receiving a result deeming them to be incompatible. Further, the study suggested that factors affecting their decisions included social stigma, that wedding plans could not be canceled. Despite these findings, the prevalence of consanguinity remains high in KSA at 56\%, with marriage between first-degree cousins (33.6\%) being more common

Disclosure. Authors have no conflict of interests, and the work was not supported or funded by any drug company. than that among other relatives (22.4\%). ${ }^{13}$ Therefore, the awareness, beliefs, and behavior of the population towards the PMS program need to be examined to identify ways to reduce the prevalence of these diseases. In addition, there is a lack of educational programs on PMS in Jeddah, KSA. Therefore, such a study on the PMS program is truly needed.

The purpose of the present study was to assess the knowledge and attitude toward hemoglobinopathies PMS program among unmarried population in Jeddah, KSA. It is hoped that the present findings will help us improve awareness regarding the screening program in future.

Methods. A cross-sectional study was conducted among unmarried males and females from the general population in Jeddah, KSA, between July and December 2017. An electronic questionnaire was equally distributed among 1,000 male and 1,000 female among general population, the acceptance rate was $86.8 \%$ in female and 17.1 in male. Ethical approval was obtained from the Institution Review Board of King Abdulaziz University Hospital in Jeddah, KSA. The sample size was calculated using the following equation:

$$
\mathrm{n}=\frac{z^{2} \times p \times q}{d^{2}}
$$

As the prevalence of knowledge regarding the PMS program among the general population, the $p$-value was unknown, it was estimated to be $50 \% \quad(p=0.5$, $p=1-0.5$, and $p=0.04$ ) was chosen as an acceptable limit of precision (d). At a 95\% confidence limit, the calculated size of the sample was 1000 participants. This number was exceeded, as the number of participants reached 1039. All the participants were informed about the study and consent was obtained. In this study, an electronic questionnaire was used for data collection. The questionnaire was composed of the following 3 parts:

Part 1: Sociodemographic characteristics. This section of the questionnaire elicited sociodemographic information from the participants, using 12 questions related to factors such as age, gender, educational level, marital status and place of residence, level of family income, level of father's education, level of mother's education, and family history of SCA and thalassemia.

Part 2: Knowledge. These questions assessed the participants' knowledge regarding the PMS program. Specifically, it contained items related to the importance of PMS, source of information, included diseases, hospitals where the test can be performed, and knowledge about the compatible and incompatible 
certificate provided based on the test results. "Correct" and "wrong" answers are scored one or "I don't know" scored zero. The total score varied from $0-23$ points, classified into the following 3 levels; scores $\leq 14$ points considered as poor knowledge, while fair knowledge ranging from $15-18$ points and good knowledge $\geq 19$ points.

Part 3: Attitude towards PMS. The questions in this section of the questionnaire assessed participants' attitudes towards the PMS program. It contained 6 statements. Responses were coded in a 5-point Likert scale (ranged from $1=$ strongly disagree to $5=$ strongly agree). These statements were measured by calculating the attitude score, which ranged from 6-30, and was classified as follows; negative attitude ranged from 6-18 points, neutral attitude from 19-24 points and positive attitude: 25-30 points.

Statistical analysis. The data were entered onto Microsoft Excel and analyzed using the SPSS Version 21 (IBM Corp., Armonk,NY, USA). Descriptive statistics were computed for the socio-demographic variables, including means, standard deviations, and frequency. Chi-square test was used for comparisons between the studied variables and knowledge. A $p$-value $\leq 0.05$ was considered significant.

Results. Among the 1039 participants, 868 (83.5\%) were female. The mean age of the participants was $22 \pm 3$ years and the majority of them were Saudi (86.1\%). Furthermore, most of the participants $(78.2 \%)$ had a university degree or above and $84.5 \%$ had a monthly income of $\geq 5000 /$ month. Consanguinity among participant's parents was reported and had a family history of genetic diseases (SCA and thalassemia) (Table 1).

A vast majority of the participants $(96.2 \%)$ had heard about the PMS program and the main source of their information was family and friends (82.3\%). Approximately one third of the participants obtained their information from social media (31.3\%), and the internet was a common source of knowledge (29.2\%) (Figure 1).

Figure 2 demonstrates the knowledge score of the participants regarding the PMS program; approximately half of the participants had poor knowledge scores $(51.1 \%)$ while $28.4 \%$ of them had fair and $20.5 \%$ had good scores.

The relationship between the knowledge of the participants and the studied sociodemographic variables have been summarized in Table 2. Educational level had a significant impact on the knowledge score $(p=0.000)$. Specifically, while $52.3 \%$ of the participants
Table 1 - Socio-demographic characteristics of the participants toward premarital screening program.

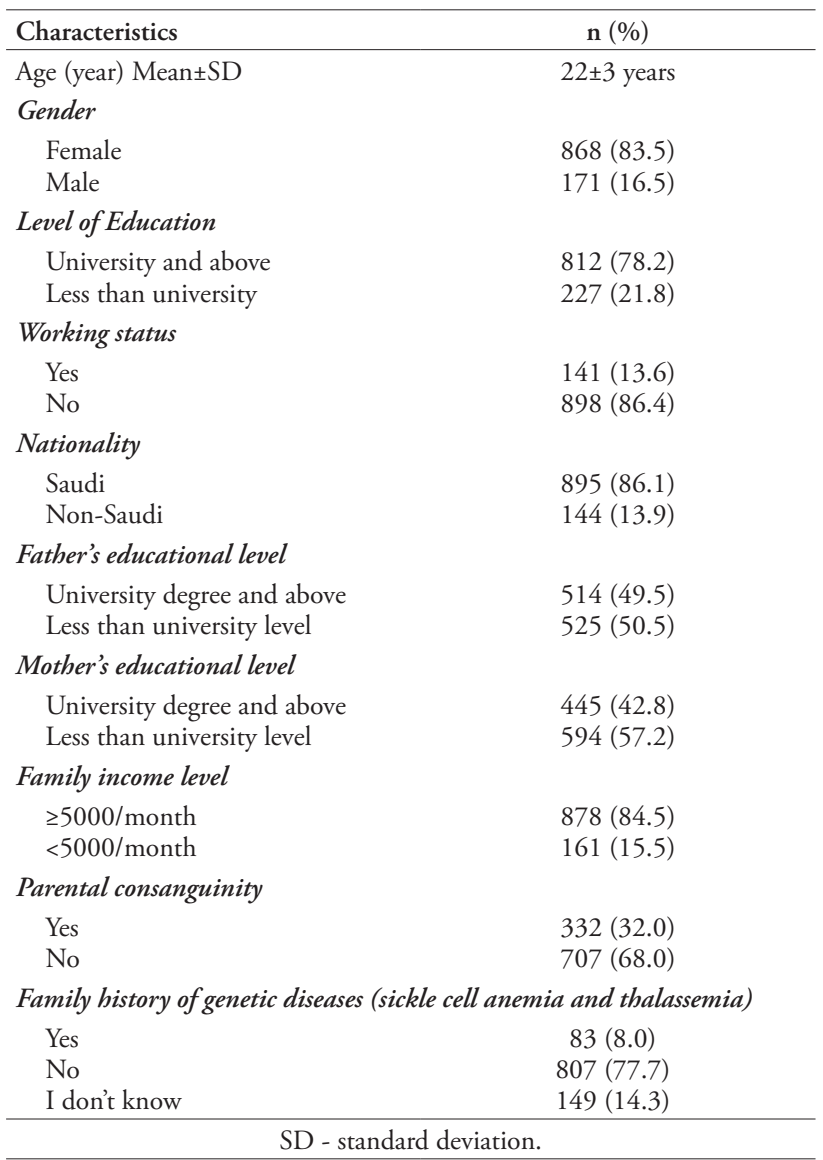

with a "university degree and above" had fair and good knowledge scores, only $36.6 \%$ of those with an educational level of "less than university" had the same. The participants aged $\geq 25$ years had more fair and good scores as compared to those aged $<25$ years, with a statistically significant difference $(p=0.005)$. Saudis had better knowledge scores as compared with non-Saudis ( $p=0.003)$, while there was no statistically significant difference in the knowledge level between genders $(p=0.108)$. Participants with a family history of genetic disease had better scores than those without did ( $p=0.000)$, This result may be explained by the existence of real cases in their lives, which would make them more aware about such diseases and their consequences and complications.

Most participants strongly agreed that PMS is a preventive measure and limits the spread of hereditary and some infectious diseases. Furthermore, almost half of the participants strongly agreed that completing the marriage in spite of incompatible results is a 


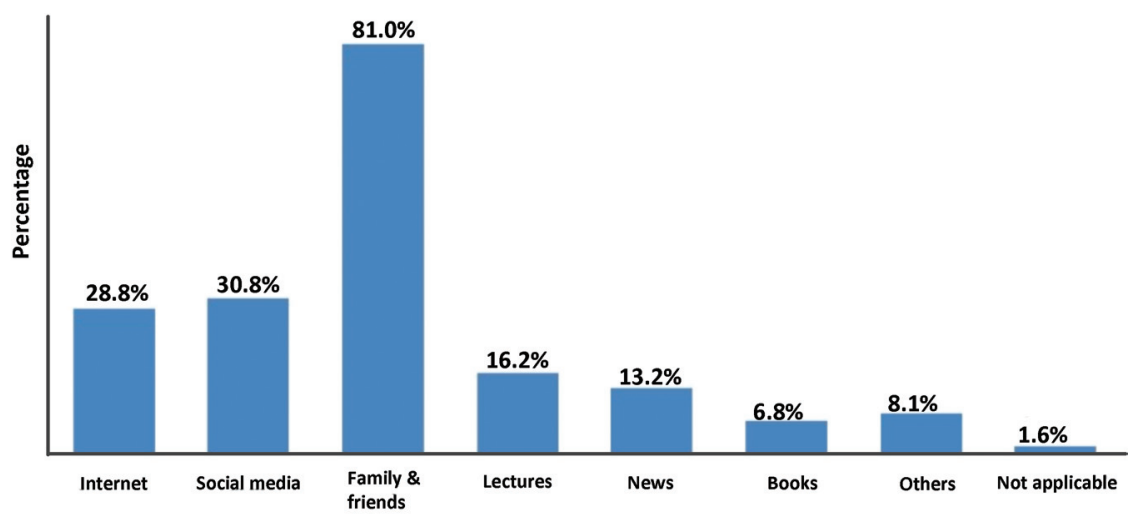

Figure 1 - Sources of knowledge regarding the pre-marital screening program.

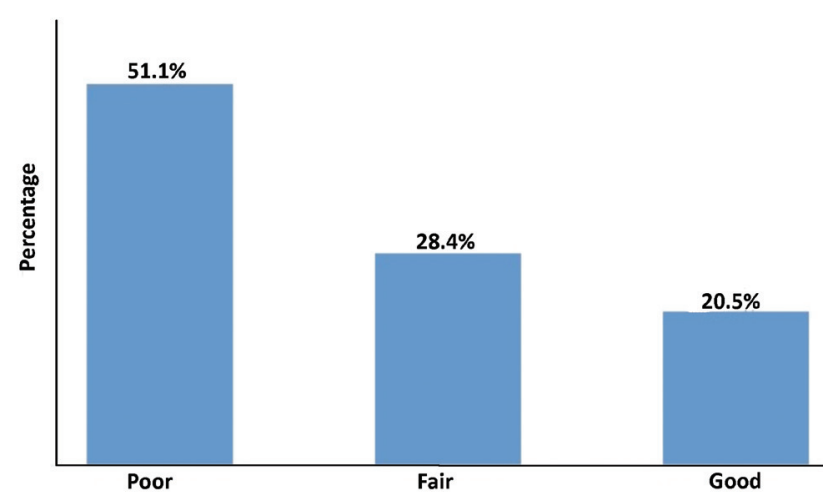

Figure 2 - Participants' level of knowledge regarding the pre-marital screening program.

wrong decision. Moreover, $40.4 \%$ of the participants strongly agreed that PMS does not break personal privacy (Table 3). Most participants $60.4 \%$ had a positive attitude toward PMS, while $32.8 \%$ had neutral and $706.7 \%$ had negative attitudes.

Discussion. The results of the current study clearly showed that participants had variable levels of knowledge regarding the PMS program. Half of them exhibited poor knowledge levels, especially regarding questions pertaining to the diseases included in PMS. These results are in line with those of previous studies conducted in Egypt, KSA, and Syria. ${ }^{8-12}$ A possible explanation for this could be the lack of early health education in schools and universities, as well as that of health campaigns among the general population, which may play a significant role in raising awareness. However, the other half of our participants showed fair and good levels of knowledge, which is similar to the findings of a study conducted by Al Sulaiman et al, ${ }^{11}$ who reported an adequate level of knowledge among Saudi participants.

In our study, the majority of the participants had heard about the PMS program from family members and friends. Thus, the knowledge in the general population can be improved further by encouraging health awareness programs for the whole community. Other important sources of information are social media and the internet. This finding is similar to those reported by other studies conducted in Pakistan, Oman, and KSA. ${ }^{4-6}$ However, another study conducted in KSA mentioned that Television and newspaper were cited as the most common sources of information. ${ }^{7}$ One of the least common sources of information was lectures, which reflects the inadequate utilization of this important educational source in universities. Consequently, knowledge regarding PMS can be improved by including the program as a fixed course in all schools and universities, as well as by conducting governmental campaigns in social media and on the internet.

In this study, the PMS knowledge score was significantly higher among participants with a higher educational level (university degree and above) as compared to their counterparts. A similar result was reported by Ibrahim et $\mathrm{al}^{12}$ based on their study conducted in Jeddah, KSA, which showed that educational level was a significant predictor of knowledge scores. Another significant finding was that participants with a family history of genetic disease had better knowledge than those without. This seems to be consistent with other studies that found that the 
Table 2 - Participants' knowledge toward premarital screening program.

\begin{tabular}{|c|c|c|c|c|}
\hline Knowledge & Poor & Fair and good & Total & $\chi^{2}(p$-value $)$ \\
\hline \multicolumn{5}{|l|}{ Age (years) } \\
\hline $\begin{array}{l}\geq 25 \\
<25\end{array}$ & $\begin{array}{r}50(36.8) \\
481(53.3)\end{array}$ & $\begin{array}{r}86(63.2) \\
422(46.7)\end{array}$ & $\begin{array}{l}903 \\
136\end{array}$ & $12.882(0.000)$ \\
\hline \multicolumn{5}{|l|}{ Gender } \\
\hline $\begin{array}{l}\text { Female } \\
\text { Male }\end{array}$ & $\begin{array}{r}434(50.0) \\
97(56.7)\end{array}$ & $\begin{array}{r}434(50.0) \\
74(43.3)\end{array}$ & $\begin{array}{l}868 \\
171\end{array}$ & $2.586(0.108)$ \\
\hline \multicolumn{5}{|l|}{ Nationality } \\
\hline $\begin{array}{l}\text { Saudi } \\
\text { Non-Saudi }\end{array}$ & $\begin{array}{r}441(49.3) \\
90(62.5)\end{array}$ & $\begin{array}{r}454(50.7) \\
54(37.5)\end{array}$ & $\begin{array}{l}895 \\
144\end{array}$ & $8.684(0.003)$ \\
\hline \multicolumn{5}{|l|}{ Level of education } \\
\hline $\begin{array}{l}\text { University degree and above } \\
\text { Less than university }\end{array}$ & $\begin{array}{l}387(47.7) \\
144(63.4)\end{array}$ & $\begin{array}{r}425(52.3) \\
83(36.6)\end{array}$ & $\begin{array}{l}812 \\
227\end{array}$ & $17.670(0.000)$ \\
\hline \multicolumn{5}{|l|}{ Family income level } \\
\hline $\begin{array}{l}\geq 5000 / \text { month } \\
<5000 / \text { month }\end{array}$ & $\begin{array}{l}427(48.6) \\
104(64.6)\end{array}$ & $\begin{array}{r}451(51.4) \\
57(35.4)\end{array}$ & $\begin{array}{l}878 \\
161\end{array}$ & $13.874(0.000)$ \\
\hline \multicolumn{5}{|l|}{$\begin{array}{l}\text { Family history of genetic diseases } \\
\text { (SCA and thalassemia) }\end{array}$} \\
\hline $\begin{array}{l}\text { Yes } \\
\text { No } \\
\text { I don't know }\end{array}$ & $\begin{array}{r}26(31.3) \\
406(50.3) \\
99(66.4)\end{array}$ & $\begin{array}{r}57(68.7) \\
401(49.7) \\
50(33.6)\end{array}$ & $\begin{array}{r}83 \\
807 \\
149\end{array}$ & $27.228(0.000)$ \\
\hline
\end{tabular}

Table 3 - Participants' attitude towards premarital screening program.

\begin{tabular}{|c|c|c|c|c|c|}
\hline Statement & $\begin{array}{l}\text { Strongly } \\
\text { disagree }\end{array}$ & Disagree & I don't know & Agree & $\begin{array}{c}\text { Strongly } \\
\text { agree }\end{array}$ \\
\hline PMS is a preventive measure & $3(0.3)$ & $\begin{array}{ll}7 & (0.7)\end{array}$ & $29(2.8)$ & $114(11.0)$ & $886(85.3)$ \\
\hline PMS must be taken in law & $34(3.3)$ & $151(14.5)$ & $163(15.7)$ & $223(21.5)$ & $468(45.0)$ \\
\hline $\begin{array}{l}\text { PMS limits hereditary \& } \\
\text { infectious diseases }\end{array}$ & $2(0.2)$ & $12 \quad(1.2)$ & $64 \quad(6.2)$ & $228(21.9)$ & $733(70.5)$ \\
\hline $\begin{array}{l}\text { Completing the marriage in spite } \\
\text { of negative results is a wrong } \\
\text { decision }\end{array}$ & $42(4.0)$ & $88 \quad(8.5)$ & $175(16.8)$ & $230(22.1)$ & $504(48.5)$ \\
\hline $\begin{array}{l}\text { You will cancel the marriage with } \\
\text { incompatible results }\end{array}$ & $27(2.6)$ & $61(5.9)$ & $291(28)$ & $204(19.6)$ & $456(43.9)$ \\
\hline $\begin{array}{l}\text { PMS violates privacy of } \\
\text { candidates }\end{array}$ & $75(7.2)$ & $79(7.6)$ & $171(16.5)$ & $294(28.3)$ & $420(40.4)$ \\
\hline
\end{tabular}

presence of a family history of genetic diseases among students was associated with a significantly higher level of knowledge. ${ }^{3}$ This result may be explained by the existence of real cases in their lives, which would make them more aware about such diseases and their consequences and complications. However, a study conducted in Riyadh, KSA by Abdullah et al, ${ }^{14}$ found that the presence of family history of genetic disease did not influence PMS knowledge significantly.

The present study revealed that participants had a positive attitude toward PMS. Similar findings have been reported previously. ${ }^{11,12}$ Approximately three- quarters of our participants strongly agreed that PMS is a preventive measure that limits the spread of hereditary and some infectious diseases. This may explain why most of the participants had positive perceptions regarding the importance of PMS in controlling and reducing the spread of hereditary and infectious diseases in the society.

A study conducted by Al-Hamdan et $\mathrm{al},{ }^{8}$ found that around $90 \%$ of the couples get married despite receiving an incompatible result. In the present study, we asked the participants about the possible causes behind this, 


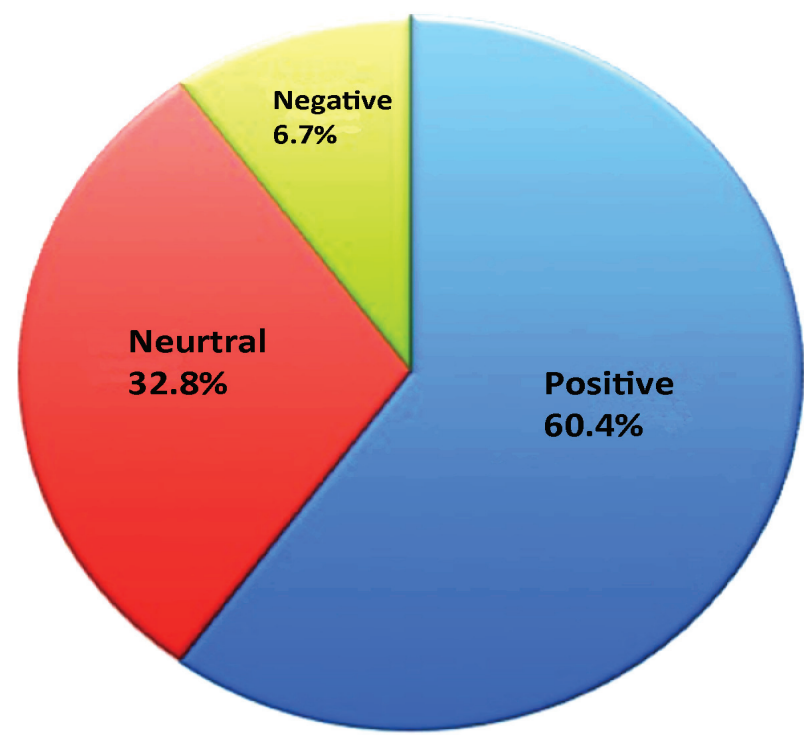

Figure 3 - Participants' attitude toward the pre-marital screening program.

and a vast majority of them $(82.96 \%)$ reported love and emotional pressure as the main reason, followed by family pressure $(52.4 \%)$. Moreover, a study conducted by Hejri, ${ }^{6}$ found that the main reason was social stigma. This finding suggests the need to implement the PMS program at an early age to avoid such problems.

Study limitations. Although the present study reached its aims, there was an unavoidable limitation. Specifically, relatively fewer men responded to the questionnaire as compared to women, which may explain by that most of the investigator were female, which may affect the generalizability of the present results. And we encourage further study to be conducted equally among males and females.

In conclusion, this paper highlighted that the participants lacked knowledge regarding PMS and what diseases it includes; however, they had a positive attitude towards the program. More efforts need to focus on raising awareness in the public regarding PMS via social media, which is one of the most important sources of information. Educational lectures in schools and universities can also play a prominent role in improving students' knowledge levels. Finally, early genetic screening may help derive maximum benefits from the test.

Acknowledgment. The authors would like to thank all participants who completed the questionnaire, and all administrators who facilitated the same. We would also like to thank the team from the research summer school in King Abdulaziz university hospital for their help and support.

\section{References}

1. Ministry of Health Portal. Premarital Screening [Internet]. 2017 [Accessed 2017 July 21]. Available from: https://www. moh.gov.sa/en/healthawareness/beforemarriage/Pages/default. aspx

2. Wu Z, Rou K, Xu C, Lou W, Detels R. Acceptability of HIV/ AIDS counseling and testing among premarital couples in China. AIDS Educ Prev 2005; 17: 12-21.

3. Al-Arrayed SS, Hafadh N, Al-Serafi S. Premarital counseling: an experience from Bahrain. East Mediterr Health J 1997; 3: 415-419.

4. Community control of hereditary anaemias: memorandum from a WHO meeting. Bull World Health Organ 1983; 61: 63-80.

5. Hereditary anaemias: genetic basis, clinical features, diagnosis, and treatment. WHO working group. Bull World Health Organ 1982; 60: 643-660.

6. Hejri YMA, Moussa M, Bushran SA, Al-Mutairi KDA, Al-Harbi AS. Evaluating premarital screening knowledge in Saudi students. Int J Community Med Public Health 2015; 2: 540-551.

7. Mohammed AM, Al-Hilli F, Nadkarni KV, Bhagwat GP, Bapat JP. Hemoglobinopathies and glucose-6-phosphate dehydrogenase deficiency in hospital births in Bahrain. Ann Saudi Med 1992; 12: 536-539.

8. Alswaidi FM, Memish ZA, O’Brien SJ, Al-Hamdan NA, Al-Enzy FM, Alhayani OA, et al. At-risk marriages after compulsory premarital testing and counseling for $\beta$-thalassemia and sickle cell disease in Saudi Arabia, 2005-2006. J Genet Couns 2012; 21: 243-255.

9. Qari AA, Balobaid AS, Rawashdeh RR, Al-Sayed MD. The development of genetic counseling services and training program in Saudi Arabia. J Genet Couns 2013; 22: 835-838.

10. Ministry of Health. Guide of Healthy Marriage Program: General directorate of non-communicable diseases [Updated 2014, Accessed 2015 August 20]. Available at: http://www. moh.gov.sa/en/HealthAwareness/Beforemarriage/Pages/ default.aspx.

11. Al Sulaiman A, Suliman A, Al Mishari M, Al Sawadi A, Owaidah TM. Knowledge and attitude toward the hemoglobinopathies premarital screening program in Saudi Arabia: populationbased survey. Hemoglobin 2008; 32: 531-538.

12. Ibrahim NK, Bashawri J, Al Bar H, Al Ahmadi J, Al Bar A, Qadi M, et al. Premarital Screening and Genetic Counseling program: knowledge, attitude, and satisfaction of attendees of governmental outpatient clinics in Jeddah. J Infect Public Health 2013; 6: 41-54.

13. El-Mouzan MI, Al-Salloum AA, Al-Herbish AS, Qurachi MM, Al-Omar AA. Regional variations in the prevalence of consanguinity in Saudi Arabia. Saudi Med J 2007; 28: 1881-1884.

14. Alghamdi AM, Alqadheb AF, Alzahrani AM, Aldhahri AS, Alsharif ZM. Knowledge of premarital screening among male university students in Riyadh, Saudi Arabia. Int J Med Sci Public Health 2016; 5: 735-742. 